\title{
STUDENTS' PERCEPTIONS OF USING E-COMICS AS A MEDIA IN MATHEMATICS LEARNING
}

\author{
Yulinar Safitri", Mailizar, Rahmah Johar \\ Universitas Syiah Kuala, Indonesia
}

\begin{tabular}{l}
\hline \hline Article Info \\
\hline Article history: \\
Received Feb 23, 2021 \\
Revised July 13, 2021 \\
Accepted July 14, 2021 \\
\hline
\end{tabular}

\section{Keywords:}

E-Comic,

Media,

Students Perceptions,

TAM

\begin{abstract}
The development of technology in education greatly influences learning strategies. Thus, teachers must adapt and present interesting and technologybased learning, such as e-comics. Therefore, the teacher must see in advance the extent to which students will accept e-comics for use in learning mathematics. This research aimed to determine students' perceptions of the use of e-comics as a media in mathematics learning. This research implemented a quantitative approach with a survey method. The samples were 124 students of Junior High Schools (SMP / MTs) in Aceh. The research data were obtained from questionnaires filled by students which were collected through the TAM (Technology Acceptance Models) framework which was distributed online. The results showed that students used e-comic as a learning media influenced by their perceived benefits and attitudes towards the use of e-comic. The perceived benefits of students' attitudes have a significant role in their behavioral intention to use e-comic in learning mathematics. This research implies that e-comics has the potential to be used as a media in mathematics learning, especially on material that is considered difficult so that it can attract students' attention.
\end{abstract}

Copyright (C) 2021 IKIP Siliwangi. All rights reserved.

\author{
Corresponding Author: \\ Yulinar Safitri, \\ Departement of Mathematics Education, \\ Faculty of Teacher Training and Education, \\ Universitas Syiah Kuala \\ Jl. Tgk. Hasan Krueng Kalee, Kopelma Darussalam, Banda Aceh, Aceh 24415, Indonesia \\ Email: yulinar.s@mhs.unsyiah.ac.id
}

\section{How to Cite:}

Safitri, Y., Mailizar, M., \& Johar, R. (2021). Students' perceptions of using e-comics as a media in mathematics learning. Infinity, 10(2), 319-330.

\section{INTRODUCTION}

Mathematics is the science that deals with the logic, problem-solving, applying logic to real-life situations. Problem-solving in real situation involves rational, exponential, and logarithmic functions. However, achieving learning objectives can pose challenges for teachers, especially concerning learning duration. Therefore, teachers must find strategies to optimize the available duration. As stated by Mamolo (2019), teachers can find more interesting ways when dealing with students, one of which is by developing learning media suitable for students of the 21 st century.

The topic will be easier for students to understand if they are presented attractively, making students more enthusiastic, motivated, and willing to participate actively in learning. The use of media in learning can help in describing a concept better and easier. The learning 
media used must be following the overall learning objectives so that they can play their roles properly and effectively in the learning system.

One of the media that can support mathematics learning activities is comics. Comics can be defined as a cartoon that expresses characters and implements a story in a sequence that is closely related to images designed to entertain the readers. Comics has a storyline that expresses an imagination and tells stories in an interrelated sequence, by combining pictures and writing designed to provide entertainment to readers. Comics has an instructional role in raising student's interest. The use of comics can help students capture abstract things or formulas.

Along with current technological development that influences the planning of learning strategies, teachers can present their learning in electronic form. Electronic-based learning media are expected to meet the needs of students in the 21 st century who are considered residents of the digital era. As expressed by Kristanto, Mustaji, and Mariono (2017), there are already many that implement electronic-based learning media because they are the current global issue.

Some people have developed comics as a medium of teaching for different subjects, levels of education, and educational objectives (Lazarinis et al., 2015). Comics used in the teaching and learning process can increase motivation and stimulation of learning activities, and it has a psychological effect on students (Buchori \& Setyawati, 2015). Besides, comics can also increase student motivation and interest (Toh et al, 2017) and creates fun learning (Özdemir, 2017). The use of cartoons can help to decrease anxiety in learning mathematics (Clair, 2018). The use of cartoons in teaching encourages students to express problems experienced and makes students realize that mathematics instruction is not only about giving "short correct answers" but also involves rich dialogues. Their imagination and creativity are set free (Clair, 2018). Therefore, e-comics are needed to achieve learning objectives and make learning more interesting's so that students are more active and motivated in learning.

Introducing technology to students is an important aspect to see the extent of acceptance and use of technology, the success of technology-based learning systems will also not be achieved if students cannot use the system (McFarland \& Hamilton, 2006; Pituch \& Lee, 2006; Yeou, 2016). Hence, it is very urgent to know the of students so that the use of technology is successful, such as the use of e-comic in learning mathematics. Many studies on the use of electronic learning have been applied, one of which is about E-learning. The use of E-learning must consider intentions and behavior (Cigdem \& Topcu, 2015).

In research on the use of technology-based systems, the Technology Acceptance Model (TAM) popularized by Davis (1989) is most often cited. TAM is specifically designed to describe and predict user acceptance of certain types of technology. TAM suggests that perceived usefulness (PU) and perceived ease of use (PEU) are important factors in influencing individual attitudes toward using technology (Nagy, 2018). In the same model, user attitudes are hypothesized to influence behavioral intentions to use the technology. In addition, external factors also affect the usability and ease of use of the system.

According to Davis (1989), various external factors or stimuli can influence students' behavior. In this research, there were four factors or indicators of TAM which were used, without expanding TAM by adding external factors. This effort would increase the effectiveness of TAM and its relevance to the indicators of PEU, PU, AT, and IU to use the system. Based on previous explanations, this research aimed to determine the students' perceptions of the use of e-comics as a media in mathematics learning.

The technology acceptance model (TAM) is based on the Theory of Reasoned Action (TRA) in psychological research (Fishbein \& Ajzen, 1975). According to TRA, individual behavior to do something is influenced by intention. TRA is presented in Figure 1. 


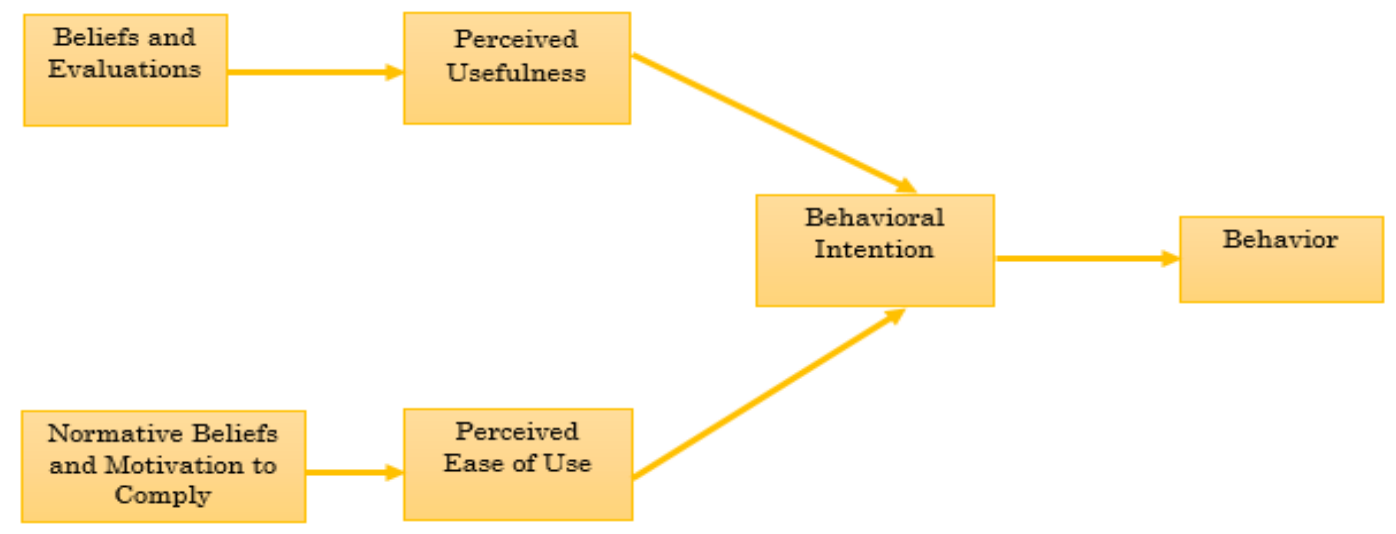

Figure 1. TRA (Theory of Reasoned Action)

According to the flowchart in Figure 1, TRA has six variables. Among them are believers and evaluations, perceived usefulness, normative beliefs and motivation to comply, perceived ease of use, behavior, and behavior intention. The principal variable is behavior, which is influencing by behavior intention. While Behavior Intention influenced by PU and PEU, as well as PU originally based on the beliefs and evaluations and PEU by normative beliefs and motivation to comply.

Meanwhile, TAM argues that perceived ease of use and perceived usefulness were the drivers of user attitudes, while perceived ease of use was also considering to affect perceived usefulness. Figure 2 the original version of TAM (Davis, 1989).

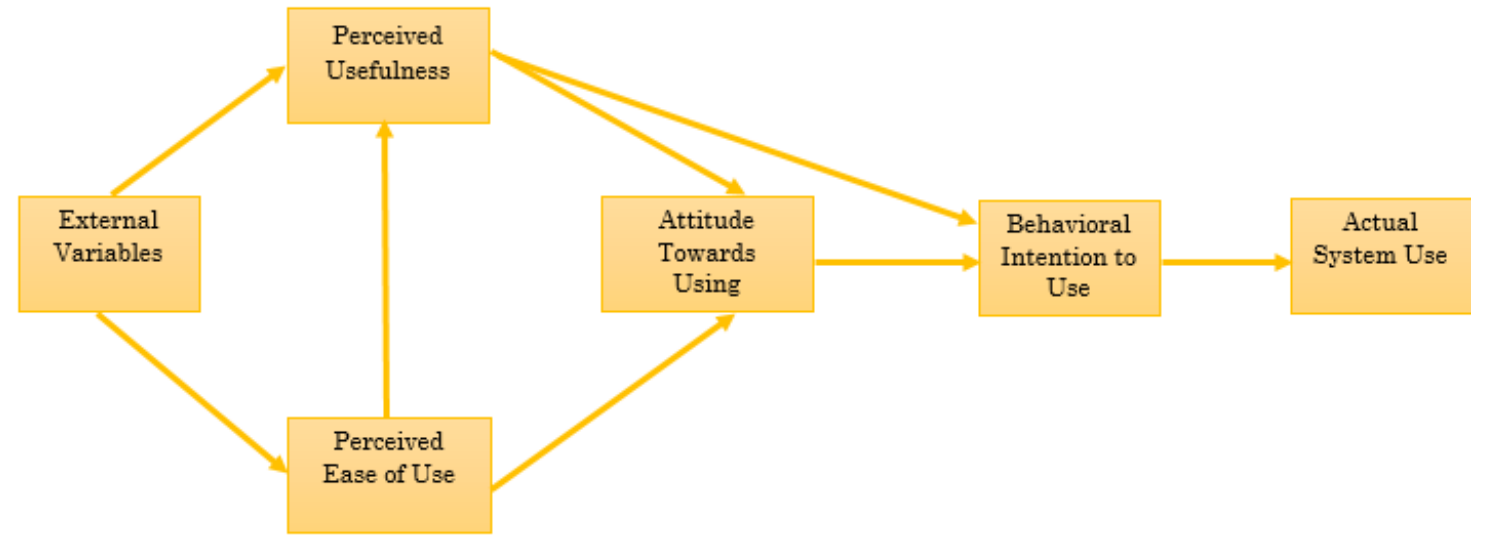

Figure 2. TAM (Technology Acceptance Model)

Figure 2 is the framework used to investigate how and when users adopt emerging technologies. TAM has proven appropriate to show the relationship between PEU, PU, AT, and BI. Accord to Davis (1989), BI is influenced by AT and is also influenced by PEU and PU, but not vice versa.

TAM has been applied in various research to test user acceptance of information technology, such as Mobile Library (Rafique et al., 2020), M-learning (Al-Emran, Mezhuyev, \& Kamaludin, 2018), E-books (Liao et al., 2018), Online Teaching (Wingo, Ivankova, \& Moss, 2017), statistical learning platform (Song \& Kong, 2017), and E-Service (Taherdoost, 2018). In this research, e-comics is considered as a media that utilizes internet and web technology to convey information to achieve learning objectives in which students can interact directly through computers or smartphones. 
In the acceptance and use of technology, TAM is considered the most popular inquiry model (Abdullah \& Ward, 2016). Legris, Ingham, and Collerette (2003) stated that the use of the TAM framework can be added by other variables to provide a better explanation of the use of technology. Research has expanded TAM by adding external variables, such as motivation (Zain et al., 2019), teacher self-efficacy (Teeroovengadum, Heeraman, \& Jugurnath, 2017), self-efficacy and enjoyment (Abdullah, Ward, \& Ahmed, 2016), selfesteem (Cheng, 2019), and information quality, system quality, and service quality (Chi, 2018). The variables used in this research were Perceived Ease of Use (PEU), Perceived Usefulness (PU), Attitude towards Using (AT), and Intention to Use (IU), all based on the TAM framework.

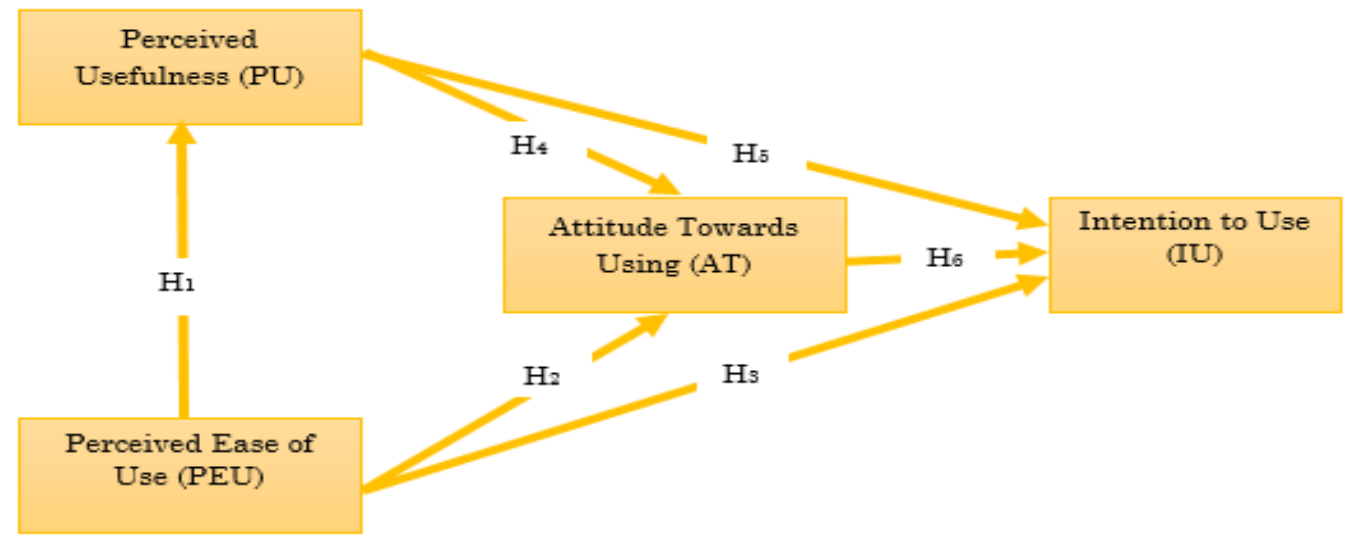

Figure 3. Structural model and hypothesis

Based on the flowchart in Figure 3, the hypothesis to be tested is to see whether PU is influenced by PEU, AT is influenced by PU and PEU, and IU is driven by PEU, PU, and AT.

Perceived Ease of Use (PEU) is defined as the extent to which technology is easy to use (Moore \& Benbasat, 1991). In this research, PEU is defined as the extent to which users believe that e-comics is easy to use in mathematics learning. The findings showed that technology acceptance increases along with the increase of PEU (Huang, 2017). Nikou and Economides (2017) found that PEU affects PU, and both factors can cause IU. There is a relationship between PEU and PU, and both have an impact on AT (Revythi \& Tselios (2019), but not on IU (Huang, 2016). Another study investigating the relationship between PEU and PU showed that PEU had no direct effect on PU (Tsai et al., 2017).

This research decided to use PEU indicator to see the extent students used e-comics in mathematics learning and the influence of PEU on PU, AT, and IU. The researchers hoped that PEU would influence PU, AT, and IU, and students would continue to use e-comics in mathematics learning in the future. Then, the following hypothesis 1 , hypothesis 2 , and hypothesis 3 were proposed.

H1: PEU has a significant influence on PU in using e-comics in mathematics learning. $\mathrm{H} 2$ : PEU has a significant influence on AT in using e-comics in mathematics learning. H3: PEU has a significant influence on IU in using e-comics in mathematics learning.

Perceived Usefulness (PU) is defined as the level at which users believe that a particular system will improve its performance (Davis, 1989). In this research, PU is defined as the extent to which users believe that using e-comics in mathematics learning will improve their learning performance. From the perspective of TAM theory, it shows that when someone intends to do something, PU is a precursor to a person's IU before they commit 
their act. There are some literature reviews in different academic fields (Khor, 2014; Tarhini et al., 2013; 2014; Wu \& Zhang, 2014) regarding the importance of PU in the adoption of new technologies. Users who believe in the benefits of using technology will accept the technology (Davis, 1989) and consequently influence the intention to use technology (Joo, Park, \& Shin, 2017). In addition, when the use of technology is considered useful, users will use the technology (Gao, Krogstie, \& Siau, 2014; Saroia \& Gao, 2019).

This research implemented PU indicator to see the extent to which students use ecomics in mathematics learning with the influence of PU on AT and IU. The researchers hope that PU could influence students' AT and students' intention to continue using e-comics in mathematics learning in the future. Therefore, hypothesis 4 and hypothesis 5 were proposed.

H4: PU has a significant influence on AT in using e-comics in mathematics learning. H5: PU has a significant influence on IU in using e-comics in mathematics learning.

Attitude Towards Using (AT) is acceptance or rejection when someone uses technology. The results showed that attitudes affect individual behavior. This attitude consists of cognitive, affective and behavioral components. Many studies have investigated AT in technology acceptance and findings suggest that IU can be increased by AT (Ibili et al., 2019).

In this research, AT indicator is to measure students' acceptance or rejection of the use of e-comics in mathematics learning. The researcher hoped that AT could influence students' IU to use e-comics in mathematics learning. Hence, hypothesis 6 was proposed.

H6: AT has a significant influence on IU in using e-comics in mathematics learning.

Intention to Use (IU) is a behavioral tendency to continue using technology in the future. Many studies have investigated IU regarding technology acceptance such as Nikou and Economides (2019) which investigated technology in science and IU of mathematics teachers to use mobile-based assessment in their teaching environment. The findings showed that PEU is the most important determinant of teacher IU to use mobile-based assessment. A study by Sánchez-Prieto, Olmos-Migueláñez, and García-Peñalvo (2017) said that PU on IU is influenced by PEU, and that the two variables have a direct influence on IU. In this research, the researchers measured students' IU for using e-comics in mathematics learning.

\section{METHOD}

The data for this study were collected using a survey method in collecting qualitative data which comprise statements on students' perceptions about e-comic in learning mathematics. Descriptive statistics were used to analyze the responses on the questionnaire. The questionnaire was used to answer research questions. Statistical Package for the Social Sciences (SPSS) was used to analyze the different indicators for students' acceptance of ecomic in learning mathematics and the interrelationships between these indicators.

In this study, 124 secondary school students in Aceh from over 10 schools were surveyed. Of the participating students, $52.4 \%$ were female $(n=65)$ and $47.6 \%$ were male $(n=59)$. Students who fill out the questionnaire are students who never have used mathematics e-comic in learning. However, students have been introduced to e-comic which will be used as a medium in learning mathematics. The content of mathematics learning in the e-comic has gone through the validation stages by several experts and has been declared valid. Likewise, e-comic has also been validating by several experts who are experts in the field of comics. 
The instrument used to measure student perceptions was questionnaires with TAM (Technology Acceptance Model) framework, adapted from Masrom (2007). The measured aspects were Perceived Ease of Use (PEU), Perceived Usefulness (PU), Attitude towards Using (AT), and Intention to Use (IU). The questionnaire was a closed-questionnaire form. The validity of the questionnaire has been tested with Cronbach's alpha as presented in Table 1. The research data were obtained online. Each student was asked to complete an online questionnaire showing their agreement or disagreement with each statement on a 7-point Likert scale with the final points at both ends being "strongly disagree" and "strongly agree". In this research, SPSS was used to analyze various indicators of students' perceptions of using e-comics in mathematics learning.

Table 1. Cronbach alpha

\begin{tabular}{lcc}
\hline \multicolumn{1}{c}{ Indicator } & Items & $\boldsymbol{\alpha}$ \\
\hline Perceived Ease of Use (PEU) & 4 & 0.89 \\
Perceived Usefulness (PU) & 4 & 0.89 \\
Attitude Towards Using (AT) & 3 & 0.85 \\
Intention to Use (IU) & 3 & 0.85 \\
\hline \multicolumn{1}{c}{ Total } & 14 & - \\
\hline
\end{tabular}

\section{RESULTS AND DISCUSSION}

\subsection{Results}

Table 2 presents the correlation matrix between indicators under discussion. The results indicated that the correlation between all indicators was significant $(\mathrm{p}<0.05)$ and positive. They also showed that the majority of the correlation coefficient ( $r$ ) was greater than 0.5 which means that the correlation between the two variables was very strong. Among all indicators, it was found that the PEU $\rightarrow$ PU showed a high $r$-value of 0.690 ( $p<0.01$ ) while the $\mathrm{r}$-value of $\mathrm{AT} \rightarrow \mathrm{IU}$ was the lowest 0.445 . This indicated that the correlation between the two indicators was very strong.

Table 2. The correlation matrix

\begin{tabular}{ccccc}
\hline Indicator & PEU & PU & AT & IU \\
\hline PEU & $\mathbf{1 . 0 0 0}$ & & & \\
PU & $0.690^{* *}$ & $\mathbf{1 . 0 0 0}$ & & \\
AT & $0.481^{* *}$ & $0.593^{* *}$ & $\mathbf{1 . 0 0 0}$ & \\
IU & $0.450^{* *}$ & $0.522^{* *}$ & $0.445^{* *}$ & $\mathbf{1 . 0 0 0}$ \\
\hline
\end{tabular}

**. Correlation is significant at the 0.01 level (2-tailed)

Table 3 presents the hypotheses testing of the structural model. The results showed that among the three independent variables, PU indicator was the largest contributor to the dependent variable PEU (PU $\rightarrow$ PEU; $\beta=0.581$ ). While for the independent variable, the AT indicator was the biggest contributor to the dependent variable PU (AT $\rightarrow \mathrm{PU} ; \beta=0.450)$. On the other hand, the IU indicator was the only contributor to the independent variable AT $(\mathrm{IU} \rightarrow \mathrm{AT} ; \beta=0.445)$. 
Table 3. Multiple regression analysis

\begin{tabular}{cccccccc}
\hline DV & $\mathbf{R}^{2}$ & IV & $\begin{array}{c}\text { Beta } \\
(\boldsymbol{\beta})\end{array}$ & $\begin{array}{c}\text { Standard } \\
\text { Error of } \boldsymbol{\beta}\end{array}$ & $\begin{array}{c}\mathbf{t}- \\
\text { statistic }\end{array}$ & Significance & Hypothesis \\
\hline PEU & 0.492 & PU & 0.581 & 0.082 & 6.709 & $0.000(p<0.001)$ & H1 \\
& & AT & 0.089 & 0.103 & 1.080 & $0.282(p>0.05)$ & H2 \\
& & IU & 0.108 & 0.091 & 1.384 & $0.169(p>0.05)$ & H3 \\
PU & 0.434 & AT & 0.450 & 0.101 & 5.894 & $0.000(p<0.001)$ & H4 \\
& & IU & 0.322 & 0.094 & 4.213 & $0.000(p<0.001)$ & H5 \\
AT & 0.198 & IU & 0.445 & 0.075 & 5.485 & $0.000(p<0.001)$ & H6 \\
\hline
\end{tabular}

Figure 4 presents the results of the hypotheses model, while the results of testing the hypothesis are presented in Table 4. For PEU, the results showed that PU indicator (H1: PEU $\rightarrow$ PU; $\beta=0.581, p<0.001)$ significantly influenced PEU. Meanwhile, AT indicator $(\mathrm{H} 2: \mathrm{PEU} \rightarrow \mathrm{AT} ; \beta=0.089, \mathrm{p}>0.05)$ and IU indicator $(\mathrm{H} 3: \mathrm{PEU} \rightarrow \mathrm{IU} ; \beta=0.108, \mathrm{p}>0.05)$ did not significantly influence PEU. These three indicators represented $49.2 \%$ of the PEU variant.

PU indicator $(\mathrm{H} 4: \mathrm{PU} \rightarrow \mathrm{AT} ; \beta=0.450, \mathrm{p}<0.001)$ showed a positive significant correlation with AT and IU indicators (H5: PU $\rightarrow$ IU; $\beta=0.322, p<0.001$ ). These two indicators explained $43.4 \%$ of the variant in PU. Meanwhile, the AT indicator (H6: AT $\rightarrow$ IU; $\beta=0.445, p<0.001)$ significantly influenced IU with a positive influence, as well as a $19.8 \%$ variant in AT.

Table 4. Results of hypothesis

\begin{tabular}{ccccc}
\hline Hypothesis & Effects & Direction & $\begin{array}{c}\text { Path } \\
\text { Coefficient }\end{array}$ & $\begin{array}{c}\text { Result } \\
\text { (Support to Hypotheses) }\end{array}$ \\
\hline $\mathrm{H}_{1}$ & $\mathrm{PEU} \rightarrow \mathrm{PU}$ & Positive & 0.695 & Supported \\
$\mathrm{H}_{2}$ & $\mathrm{PEU} \rightarrow \mathrm{AT}$ & Negative & 0.096 & Not Supported \\
$\mathrm{H}_{3}$ & $\mathrm{PEU} \rightarrow \mathrm{IU}$ & Negative & 0.169 & Not Supported \\
$\mathrm{H}_{4}$ & $\mathrm{PU} \rightarrow \mathrm{AT}$ & Positive & 0.647 & Supported \\
$\mathrm{H}_{5}$ & $\mathrm{PU} \rightarrow \mathrm{IU}$ & Positive & 0.226 & Supported \\
$\mathrm{H}_{6}$ & $\mathrm{AT} \rightarrow \mathrm{IU}$ & Positive & 0.268 & Supported \\
\hline
\end{tabular}

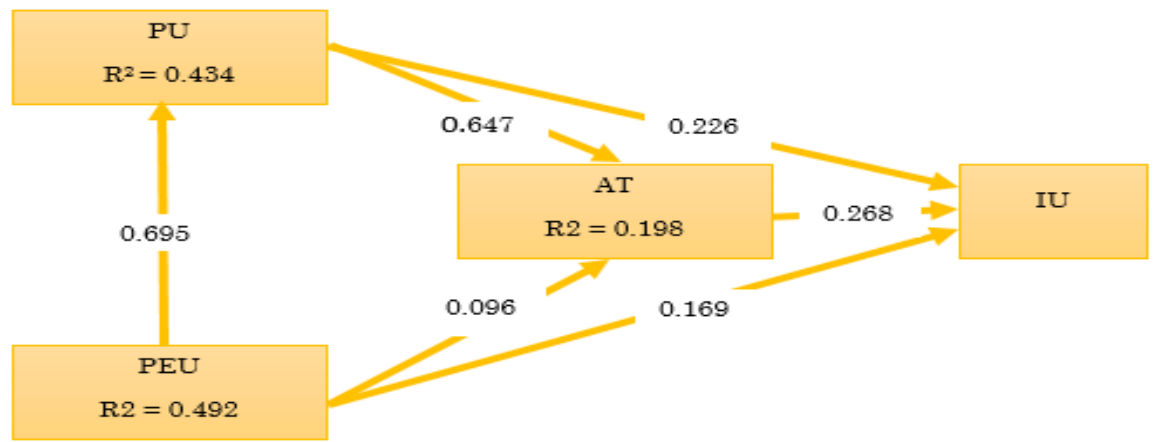

Figure 4. Hypotheses of the structural model

The flowchart shows that PEU has a positive impact on PU. PU also has a positive effect on AT and IU. However, AT also has a positive influence on IU (see Figure 4). 


\subsection{Discussion}

The main objective of this study is to examine the factors that influence high school students to use e-comic in learning mathematics. This study focus on students' perceptions of using e-comic in learning mathematics. The TAM model (Davis, 1986) was adopted without adding any external variables in this study. The results of this study show there are four points.

First, this study shows the perceived ease of use (PEU) of e-comic has a significant direct effect on the perceived usefulness (PU) of e-comic. This finding is consistent with other studies regarding the significant relationship of PEU to PU. In terms of perceived usefulness, as research by Park (2009) shows that perceived usefulness is one of the strongest determinants of the TAM model. Therefore, students who find this system useful in their education are likely to adopt the system. Therefore, improving the quality of e-comic media in learning mathematics is very necessary so that students use it.

During learning mathematics, students who used e-comic wil have many opportunities to learn because it can be used anytime and anywhere. For example, you don't need to carry books where students go, but can be accessed directly via smartphones. This study shows that the use of e-comic provides an opportunity for student to improve learning achievement. Therefore, the use of e-comics in learning mathematics, in particular, has a positive impact on the achievement of learning objectives.

Second, regarding perceived usefulness (PU), the results show that perceived usefulness has a significant relationship to user attitudes (AT). In this study, students' attitudes to using e-comic in learning mathematics were influenced by the perceived usefulness of using comics. This finding is following the hypothesis in this study that PU has a positive influence on students' AT to use e-comic. Previous studies have shown that Perceived Usefulness (PU) is important for predicting Attitudes towards Technology Use (ATU). This result also agrees with that reported by Davis (the predecessor of TAM theory), who assumes that Perceived Usefulness (PU) is one of the top indicators of user attitudes (ATU) (Davis, 1989; Davis, Bagozzi, \& Warshaw, 1989; Venkatesh \& Davis, 2020).

The third is regarding the behavior (UI) of students to use e-comic in learning mathematics. The results show that (UI) has a significant effect on PU and AT. Previous studies have also proven attitude (AT) is very important for behavioral intention (Hussein, 2017; Taat \& Francis, 2020). Other results show that PEU is not significantly and positively related to UI. Previous research showed a similar finding that PEU (Lew et al., 2019) was not significant for the prediction of IU's behavioral intention to use E-learning.

The findings of this study indicate that the ease of using e-comic does not guarantee students to use e-comic during mathematics learning. In this case, attitude is an important factor that determines the use of e-comics in learning mathematics. Students will use e-comic if e-comic has great benefits for learning mathematics while they are studying.

\section{CONCLUSION}

This study reveals how students perceive to use e-comic in learning mathematics, especially for high school students. The results of the study indicate that students will use ecomic in learning mathematics if influenced by the perceived benefits and attitudes towards using e-comic in using the e-comic. The perceived benefits of students' attitudes towards the use of e-comic have a very significant role in their behavioral intentions. 


\section{REFERENCES}

Abdullah, F., \& Ward, R. (2016). Developing a General Extended Technology Acceptance Model for E-Learning (GETAMEL) by analysing commonly used external factors. Computers in human behavior, 56, 238-256. https://doi.org/10.1016/j.chb.2015.11.036

Abdullah, F., Ward, R., \& Ahmed, E. (2016). Investigating the influence of the most commonly used external variables of TAM on students' Perceived Ease of Use (PEOU) and Perceived Usefulness (PU) of e-portfolios. Computers in human behavior, 63, 75-90. https://doi.org/10.1016/j.chb.2016.05.014

Al-Emran, M., Mezhuyev, V., \& Kamaludin, A. (2018). Technology Acceptance Model in M-learning context: A systematic review. Computers \& Education, 125, 389-412. https://doi.org/10.1016/j.compedu.2018.06.008

Buchori, A., \& Setyawati, R. D. (2015). Development learning model of charactereducation through e-comic in elementary school. International Journal of Education and Research, 3(9), 369-386.

Cheng, E. W. (2019). Choosing between the theory of planned behavior (TPB) and the technology acceptance model (TAM). Educational Technology Research and Development, 67(1), 21-37. https://doi.org/10.1007/s11423-018-9598-6

Chi, T. (2018). Understanding Chinese consumer adoption of apparel mobile commerce: An extended TAM approach. Journal of Retailing and Consumer Services, 44, 274-284. https://doi.org/10.1016/j.jretconser.2018.07.019

Cigdem, H., \& Topcu, A. (2015). Predictors of instructors' behavioral intention to use learning management system: A Turkish vocational college example. Computers in Human Behavior, 52, 22-28. https://doi.org/10.1016/j.chb.2015.05.049

Clair, J. S. (2018). Using cartoons to make connections and enrich Mathematics. In Proceedings of the Interdisciplinary STEM Teaching and Learning Conference (Vol. 2, pp. 45-53). https://doi.org/10.20429/stem.2018.020112

Davis, F. D. (1989). Perceived usefulness, perceived ease of use, and user acceptance of information technology. MIS quarterly, 13(3), 319-340. https://doi.org/10.2307/249008

Davis, F. D., Bagozzi, R. P., \& Warshaw, P. R. (1989). User acceptance of computer technology: A comparison of two theoretical models. Management science, 35(8), 982-1003. https://doi.org/10.1287/mnsc.35.8.982

Fishbein, M., \& Ajzen, I. (1975). Belief, attitude, intention, and behavior: An introduction to theory and research. Reading, MA: Addison-Wesley.

Gao, S., Krogstie, J., \& Siau, K. (2014). Adoption of mobile information services: An empirical study. Mobile Information Systems, 10(2), 147-171. https://doi.org/10.3233/MIS-130176

Huang, C. C. (2017). Cognitive factors in predicting continued use of information systems with technology adoption models. Information Research: An International Electronic Journal, 22(2).

Huang, Y. M. (2016). The factors that predispose students to continuously use cloud services: Social and technological perspectives. Computers \& Education, 97, 86-96. https://doi.org/10.1016/j.compedu.2016.02.016 
Hussein, Z. (2017). Leading to intention: The role of attitude in relation to technology acceptance model in e-learning. Procedia Computer Science, 105, 159-164. https://doi.org/10.1016/j.procs.2017.01.196

Ibili, E., Resnyansky, D., \& Billinghurst, M. (2019). Applying the technology acceptance model to understand maths teachers' perceptions towards an augmented reality tutoring system. Education and Information Technologies, 24(5), 2653-2675. https://doi.org/10.1007/s10639-019-09925-z

Joo, Y. J., Park, S., \& Shin, E. K. (2017). Students' expectation, satisfaction, and continuance intention to use digital textbooks. Computers in Human Behavior, 69, 83-90. https://doi.org/10.1016/j.chb.2016.12.025

Khor, E. T. (2014). An analysis of ODL student perception and adoption behavior using the technology acceptance model. International Review of Research in Open and Distributed Learning, 15(6), 275-288. https://doi.org/10.19173/irrodl.v15i6.1732

Kristanto, A., Mustaji, M., \& Mariono, A. (2017). The development of instructional materials e-learning based on blended learning. International Education Studies, 10(7), 10-17. https://doi.org/10.5539/ies.v10n7p10

Lazarinis, F., Mazaraki, A., Verykios, V. S., \& Panagiotakopoulos, C. (2015). E-comics in teaching: Evaluating and using comic strip creator tools for educational purposes. In 2015 10th International Conference on Computer Science \& Education (ICCSE) (pp. 305-309). IEEE. https://doi.org/10.1109/ICCSE.2015.7250261

Legris, P., Ingham, J., \& Collerette, P. (2003). Why do people use information technology? A critical review of the technology acceptance model. Information \& management, 40(3), 191-204. https://doi.org/10.1016/S0378-7206(01)00143-4

Liao, S., Hong, J. C., Wen, M. H., \& Pan, Y. C. (2018). Applying technology acceptance model (TAM) to explore users' behavioral intention to adopt a performance assessment system for E-book production. EURASIA Journal of Mathematics, Science and Technology Education, 14(10), em1601. https://doi.org/10.29333/ejmste/93575

Lew, S. L., Lau, S. H., \& Leow, M. C. (2019). Usability factors predicting continuance of intention to use cloud e-learning application. Heliyon, 5(6), e01788. https://doi.org/10.1016/j.heliyon.2019.e01788

Mamolo, L. (2019). Analysis of senior high school students' competency in general mathematics. Universal Journal of Educational Research,7(9), 1938-1944. https://doi.org/10.13189/ujer.2019.070913

Masrom, M. (2007). Technology acceptance model and e-learning. In 12th International Conference on Education (pp. 1-10). Sultan Hassanal Bolkiah Institute of Education Universiti Brunei Darussalam.

McFarland, D. J., \& Hamilton, D. (2006). Adding contextual specificity to the technology acceptance model. Computers in human behavior,22(3), 427-447. https://doi.org/10.1016/j.chb.2004.09.009

Moore, G. C., \& Benbasat, I. (1991). Development of an instrument to measure the perceptions of adopting an information technology innovation. Information systems research, 2(3), 192-222. https://doi.org/10.1287/isre.2.3.192 
Nagy, J. T. (2018). Evaluation of online video usage and learning satisfaction: An extension of the technology acceptance model. International Review of Research in Open and Distributed Learning, 19(1), 160-185. https://doi.org/10.19173/irrodl.v19i1.2886

Nikou, S. A., \& Economides, A. A. (2017). Mobile-based assessment: Investigating the factors that influence behavioral intention to use. Computers \& Education, 109, 5673. https://doi.org/10.1016/j.compedu.2017.02.005

Nikou, S. A., \& Economides, A. A. (2019). Factors that influence behavioral intention to use mobile-based assessment: A STEM teachers' perspective. British Journal of Educational Technology, 50(2), 587-600. https://doi.org/10.1111/bjet.12609

Özdemir, E. (2017). Humor in elementary science: Development and evaluation of comic strips about sound. International Electronic Journal of Elementary Education, 9(4), 837-850.

Park, S. Y. (2009). An analysis of the technology acceptance model in understanding university students' behavioral intention to use e-learning. Journal of Educational Technology \& Society, 12(3), 150-162.

Pituch, K. A., \& Lee, Y. K. (2006). The influence of system characteristics on e-learning use. Computers \& Education, 47(2), 222-244. https://doi.org/10.1016/j.compedu.2004.10.007

Rafique, H., Almagrabi, A. O., Shamim, A., Anwar, F., \& Bashir, A. K. (2020). Investigating the acceptance of mobile library applications with an extended technology acceptance model (TAM). Computers \& Education, 145, 103732. https://doi.org/10.1016/j.compedu.2019.103732

Revythi, A., \& Tselios, N. (2019). Extension of technology acceptance model by using system usability scale to assess behavioral intention to use e-learning. Education and Information technologies, 24(4), 2341-2355. https://doi.org/10.1007/s10639-01909869-4

Sánchez-Prieto, J. C., Olmos-Migueláñez, S., \& García-Peñalvo, F. J. (2017). MLearning and pre-service teachers: An assessment of the behavioral intention using an expanded TAM model. Computers in Human Behavior, 72, 644-654. https://doi.org/10.1016/j.chb.2016.09.061

Saroia, A. I., \& Gao, S. (2019). Investigating university students' intention to use mobile learning management systems in Sweden. Innovations in Education and Teaching International, 56(5), 569-580. https://doi.org/10.1080/14703297.2018.1557068

Song, Y., \& Kong, S. C. (2017). Investigating students' acceptance of a statistics learning platform using technology acceptance model. Journal of Educational Computing Research, 55(6), 865-897. https://doi.org/10.1177/0735633116688320

Taat, M. S., \& Francis, A. (2020). Factors influencing the students' acceptance of e-learning at teacher education institute: An exploratory study in Malaysia. International Journal of Higher Education, 9(1), 133-141. https://doi.org/10.5430/ijhe.v9n1p133

Taherdoost, H. (2018). Development of an adoption model to assess user acceptance of eservice technology: E-Service Technology Acceptance Model. Behaviour \& Information Technology, 37(2), 173-197. https://doi.org/10.1080/0144929X.2018.1427793 
Tarhini, A., Hone, K., \& Liu, X. (2013). Factors affecting students' acceptance of e-learning environments in developing countries: a structural equation modeling approach. International Journal of Information and Education Technology (IJIET), 3(1), 5459. https://doi.org/10.7763/IJIET.2013.v3.233

Tarhini, A., Hone, K., \& Liu, X. (2014). The effects of individual differences on e-learning users' behaviour in developing countries: A structural equation model. Computers in human behavior, 41, 153-163. https://doi.org/10.1016/j.chb.2014.09.020

Teeroovengadum, V., Heeraman, N., \& Jugurnath, B. (2017). Examining the antecedents of ICT adoption in education using an extended technology acceptance model (TAM). International Journal of Education and Development Using ICT, 13(3), 423.

Toh, T. L., Cheng, L. P., Ho, S. Y., Jiang, H., \& Lim, K. M. (2017). Use of comics to enhance students' learning for the development of the twenty-first century competencies in the mathematics classroom. Asia Pacific Journal of Education, 37(4), 437-452. https://doi.org/10.1080/02188791.2017.1339344

Tsai, T. H., Chang, H. T., Chen, Y. J., \& Chang, Y. S. (2017). Determinants of user acceptance of a specific social platform for older adults: An empirical examination of user interface characteristics and behavioral intention. PLoS ONE, 12(8), e0180102. https://doi.org/10.1371/journal.pone.0180102

Venkatesh, V., \& Davis, F. D. (2000). A theoretical extension of the technology acceptance model: Four longitudinal field studies. Management science, 46(2), 186-204. https://doi.org/10.1287/mnsc.46.2.186.11926

Wingo, N. P., Ivankova, N. V., \& Moss, J. A. (2017). Faculty perceptions about teaching online: Exploring the literature using the technology acceptance model as an organizing framework. Online Learning, 2l(1), 15-35. https://doi.org/10.24059/olj.v21i1.761

Wu, B., \& Zhang, C. (2014). Empirical study on continuance intentions towards E-Learning 2.0 systems. Behaviour \& Information Technology,33(10), 1027-1038. https://doi.org/10.1080/0144929X.2014.934291

Yeou, M. (2016). An investigation of students' acceptance of Moodle in a blended learning setting using technology acceptance model. Journal of Educational Technology Systems, 44(3), 300-318. https://doi.org/10.1177/0047239515618464

Zain, F. M., Hanafi, E., Don, Y., Yaakob, M. F. M., \& Sailin, S. N. (2019). Investigating student's acceptance of an EDMODO content management system. International Journal of Instruction, 12(4), 1-16. https://doi.org/10.29333/iji.2019.1241a 